\title{
EVALUATION OF TRIBOLOGICAL PROPERTIES OF POLYMER MATERIALS USED FOR SLIDING BEARINGS IN AGRICULTURAL MACHINERY
}

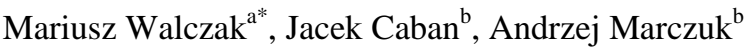 \\ ${ }^{a}$ Department of Materials Engineering, Faculty of Mechanical Engineering, Lublin University of \\ Technology \\ ${ }^{\mathrm{b}}$ Department of Transportation and Agricultural Machinery, Faculty of Production Engineering, \\ University of Life Sciences in Lublin \\ "Corresponding author: e-mail: m.walczak@pollub.pl \\ ARTICLE INFO \\ Article history: \\ Received: August 2016 \\ Received in the revised form: \\ September 2016 \\ Accepted: October 2016 \\ Key words: \\ friction coefficient, \\ sliding bearings, \\ ball-on-disc test \\ wear, \\ tribology

ABSTRACT
The continuous technological development requires the use of modern
materials also in agricultural engineering. Knowledge of the
characteristics of tribological materials pairs cooperating with each
other is useful for developing sliding nodes of agricultural machinery.
Tribological properties of materials should be assessed for selection of
technological materials beyond the economic criterion. The article
presents analysis of the characteristics of tribological ball-on-disc
wear of polymeric materials used as sliding elements for farm
machines. Tribological tests were carried out under dry friction for
a polymer-metal pair, and a wear rate and friction coefficient of the
sample; the signs of wear were submitted to SEM observations.

\section{Introduction}

Rapid global development of plastics and their applications determine higher expectations and market demands. Those factors apply to plastics quality, economics and aesthetic appearance (Szczerba, 2013). The continuous technological development requires the use of modern materials in agricultural engineering. Improving the structure and the need to ensure high quality and reliability of agricultural machinery also requires proper maintenance of machinery. This is particularly important in agricultural production, where seasonality of certain works and agricultural treatments is a significant operation problem. More and more frequently used materials in the construction of agricultural machinery are constantly high strength (supporting structure of trailers, extension arms, machine elements working in the soil) and a wide range of polymeric materials including investigated in this study polymeric materials used for sliding bearings (bearings of rotating machine elements e.g. aggregates, posterior side shredders).

Agricultural machinery works in harsh conditions, with dust, dirt, and possible chemical agents. Chemical resistance of polymers, in addition to a chemical agent, is significantly affected by physical factors, which include: temperature, variability of operating conditions (a cyclical nature of the contact of material with aggressive liquid), movement of liquid, solution concentration and interaction of organic solvents with chemically active substances 
(Gościański et al., 2005). Regardless of the impact of various chemical media and physical factors, important - from the point of view of physicomechanical properties of the material - is also exposure of the elements made of plastics and composites to UV radiation, moisture, changing mechanical stresses, the phenomena of cavitation (tanks with liquid) and destruction associated with the internal aging processes (Bugajski et al., 2002; Jachowicz and Gajdoš, 2014). Knowledge and predictability of the technical aspects of the aging process and progressive wear and tear of machinery, and equipment is essential in solving most of the problems of the construction, manufacturing and rational process of their use (Tomczyk, 2005). This knowledge allows proper construction, choosing the right manufacturing technology, optimizing complex operational parameters and the choice of optimal strategy for the use and renewal of machinery and equipment in the further process of their exploitation (Tomczyk, 2005).

The polymeric materials and their composites have recently been increasingly used in various industrial applications (Friedrich and Cyffka, 1985; Gardyński and Lonkwic, 2014; Harsha, 2011; Jachowicz and Dulebová, 2015; Shipway and Ngao, 2003). The surface layer of the polymeric sliding materials cooperating with the steel has an impact on the tribological properties (Ptak, 2016). At the design stage of construction the acceptability level of polymer materials to work in conditions of abrasive wear depends to large extent on their mechanical load and wear level which in turn translates into safety and durability of machine parts (Harsha, 2011; Nunez and Polycarpou, 2015). Friction is a very important phenomenon, as measured by various parameters that determines the choice of materials for sliding nodes, because many variables have an impact on them, e.g. working conditions of contact elements, the ability to create a polymer film (transfer of material) or generated heat (Menezesa et al., 2011). The wear resistance of materials not only depends on the mechanical and structural properties of the materials used but also on the testing technique, as it was reported in (Harsha, 2011; Bahadur and Gong, 1992; Cenna et al., 2003; Dykha and Kuzmenko, 2015; Ptak, 2016; Szczerek and Tuszyński, 2002). In case of lubrication-free polymer bearings, there is no need for maintenance, as in case of bronze or brass sleeves. In addition, these bearings ensure a long service life of the machine thanks to better vibration damping properties and in comparison to conventional bearings, they are not noisy. Good practice in selection of technological materials for sliding nodes beyond economic criteria (the cost of materials and manufacturing methods) is the assessment of the tribological properties of materials compiled. Therefore, this work deals with tribological characteristics research using ball-on-disc test, materials working as a sliding pair of polymer-metal under technical dry friction.

\section{Materials and methods}

Table 1 presents the characteristics of physical and mechanical properties of polymer materials, according to the manufacturer's data. Polymer samples used for the sliding nodes by Igus ${ }^{\circledR}$, with trade names iglidur A180, iglidur P210, and iglidur X have been applied for the tests. 
Evaluation of tribological...

Table 1.

Summary of physical and mechanical properties of researched polymer materials

\begin{tabular}{|c|c|c|c|c|}
\hline Properties & Unit & $\begin{array}{l}\text { iglidur }{ }^{\circledR} \\
\text { A180 }\end{array}$ & $\begin{array}{l}\text { iglidur }{ }^{\circledR} \\
\text { P210 }\end{array}$ & $\begin{array}{c}\text { iglidur }^{\circledR} \\
\mathrm{X}\end{array}$ \\
\hline Density & $\left(\mathrm{g} \cdot \mathrm{cm}^{-3}\right)$ & 1.46 & 1.40 & 1.44 \\
\hline Colour & $(-)$ & white & yellow & black \\
\hline $\begin{array}{l}\text { The maximum moisture absorption at } \\
23^{\circ} \mathrm{C} / 50 \% \text { r.h. }\end{array}$ & $\begin{array}{c}(\% \\
\text { weight })\end{array}$ & 0.2 & 0.3 & 0.1 \\
\hline The maximum water absorption & $\begin{array}{c}(\% \\
\text { weight }) \\
\end{array}$ & 1.3 & 0.5 & 0.5 \\
\hline Modulus of elasticity & $(\mathrm{MPa})$ & 2300 & 2500 & 8100 \\
\hline Tensile Strength at temp $20^{\circ} \mathrm{C}$ & $(\mathrm{MPa})$ & 88 & 70 & 170 \\
\hline Compressive strength & $(\mathrm{MPa})$ & 78 & 50 & 100 \\
\hline $\begin{array}{l}\text { The maximum surface pressure at } \\
20^{\circ} \mathrm{C}\end{array}$ & (MPa) & 28 & 50 & 150 \\
\hline Shore hardness & ( $\left.{ }^{\circ} \mathrm{Sh} \mathrm{D}\right)$ & 76 & 75 & 85 \\
\hline $\begin{array}{l}\text { The maximum operating temperature } \\
\text { in a long time }\end{array}$ & $\left({ }^{\circ} \mathrm{C}\right)$ & +90 & +100 & +250 \\
\hline $\begin{array}{l}\text { The maximum operating temperature } \\
\text { in a short time }\end{array}$ & ${ }^{\circ} \mathrm{C}$ & +110 & +160 & +315 \\
\hline The minimum operating temperature & ${ }^{\circ} \mathrm{C}$ & -50 & -40 & -100 \\
\hline Thermal conductivity & $\left(\mathrm{W} \cdot \mathrm{m}^{-1} \cdot \mathrm{K}\right)$ & 0.25 & 0.25 & 0.6 \\
\hline $\begin{array}{l}\text { The coefficient of thermal expansion at } \\
23^{\circ} \mathrm{C}\end{array}$ & $\left(\mathrm{K}^{-1} \cdot 10^{-5}\right)$ & 11 & 8 & 5 \\
\hline
\end{tabular}

The specimens used for tribological tests have been made in the form of discs with diameter of Ø $30 \mathrm{~mm}$ and thickness of $5 \mathrm{~mm}$. The discs have been subjected to grinding by means of water abrasive papers with the grain size of 220, 600 and 1200 correspondingly. Then, the samples have been subjected to mechanical polishing by means of diamond particles suspension $(3 \mu \mathrm{m})$ and oxides particles suspension $(0.05 \mu \mathrm{m})$, washed with acetone and dried after completed polishing.

Wear tests were conducted on a "ball-on-disc" tribotester by CSM instruments, at room temperature under technical dry friction. The balls with diameter of Ø $6 \mathrm{~mm}$ made of steel 100Cr6 (manufactured by CSM Instruments) have been used as a counter-sample (ball). The tests were carried out under the load of $10 \mathrm{~N}$ with linear speed of $0.05 \mathrm{~mm} \cdot \mathrm{s}^{-1}$ on the radius of $5 \mathrm{~mm}$. The total test distance was equal to $500 \mathrm{~m}$ and was used to record the friction coefficient change. The wear measure was equal to volumetric loss of the sample which occurred as a trace of abrasion as a result of sample and ball mating.

Therefore the surface area of sample abrasion was measured by means of Dektak 150 contact profile meter manufactured by Veeco Instruments along the sample circumference (at 15 locations). Nose radius of a measuring needle was equal to $2 \mu \mathrm{m}$. A volumetric wear was set as the product of the average value of the wear field of the sample and circumference of a circle of wear track resulting in the ball-on-disc test. Then the so-called wear factor $(K)$ was determined, which, next to volumetric wear, took into account the load and the distance used during the test (ASTM Standard, G 40-15): 
Mariusz Walczak, Jacek Caban, Andrzej Marczuk

$$
K=\frac{\text { Volumetric wear }}{\text { Loading force } \times \text { sliding distance }}\left(\mathrm{mm}^{3} \mathrm{~N}^{-1} \mathrm{~m}^{-1}\right)
$$

The surface of wear tracks of materials tested after carried out tribological tests was assessed using scanning electron microscope Phenom G2 pro (Phenom Word).

\section{Results and discussion}

Values of recorded coefficients of friction are given in Table 2, a graphical interpretation in the path function is shown in Figure 1.

Table 2.

Summary of the values of the friction coefficients of researched polymer materials

\begin{tabular}{lcc}
\hline Materials & $\begin{array}{c}\text { The average } \\
\text { friction coefficient } \mu\end{array}$ & $\begin{array}{c}\text { Standard } \\
\text { deviation }\end{array}$ \\
\hline Iglidur A180 & 0.14 & 0.02 \\
Iglidur X & 0.19 & 0.03 \\
Iglidur P210 & 0.12 & 0.05 \\
\hline
\end{tabular}

Comparative analysis of friction coefficients indicated, that the lowest coefficient of friction was observed for steam iglidur P210 - steel 100Cr6. For this pair the maximum standard deviation of \pm 0.05 is obtained. On the other hand, the largest friction coefficient is obtained for steam iglidur X - steel 100Cr6. In general, a lower friction coefficient corresponds to a polymer with a smaller hardness (see Table 1 - Shore hardness). To change the friction coefficient in the path function in all the studied cases there is a small increasing tendency of coefficient of friction, which increases smoothly along with the increasing contact field between the mating surfaces (Fig. 1). Sometimes the products of wear get to the track of the direct cooperation of a sample and counter-sample and then the momentary increase in friction coefficient is observed.

Analysis of the results shown in Figure 1 proved that iglidur P210 material has the smallest coefficient of friction in the technically dry friction environment, which is characterized by the lowest wear resistance. Then a slightly higher friction coefficient, but a much higher wear resistance was noted for the iglidur A180 material.

The values of determined wear factors $(K)$ are presented in Figure 2. With analysis of the above-mentioned results the highest wear resistance in the technically dry friction environment was observed for iglidur A180 material. However, the greatest wear was observed for iglidur P210 material, which was characterized by the lowest coefficient of friction. Such a course of usage is closely connected with the structural construction of materials tested and translates directly into the surface condition after the tribological tests. 
Evaluation of tribological...

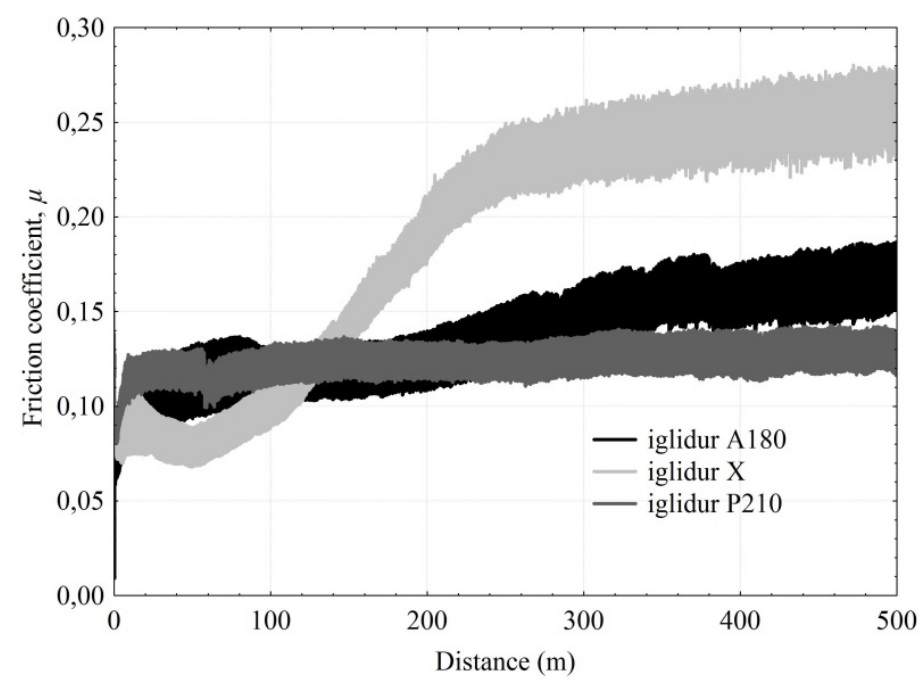

Figure 1. Charts of changes of friction coefficient recorded on a ball-on-disc stand at a distance of $500 \mathrm{~m}$ in technical dry friction conditions

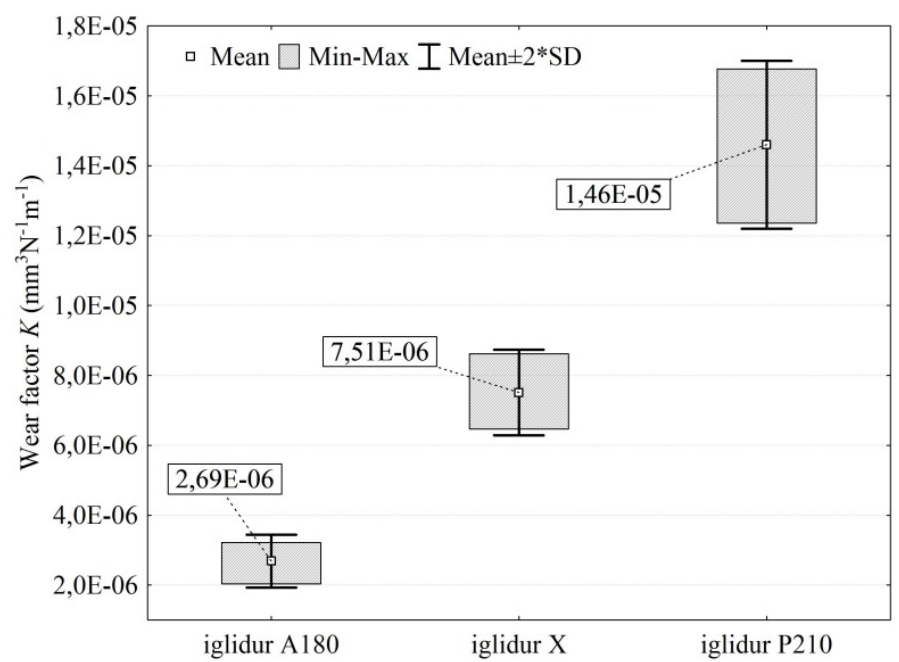

Figure 2. A graph of the values of wear factors (K)

In order to verify that the changes are indeed statistically significant, analysis was performed with the use of STATISTICA software along with parametric tests for independent trials. Statistical analysis using Shapiro-Wilk test of volumetric wear measurement showed that the results obtained have a normal distribution $\mathrm{p}>0.05$ (assuming $\alpha=0.05$ ). Respectively for iglidur material: A180, X and P210 was obtained successively: $\mathrm{p}=0.531, \mathrm{p}=0.973$ and $\mathrm{p}=0.796$, therefore $\mathrm{p}>\alpha$, there is no reason to reject a hypothesis of normal distribution of 
tested characteristics. This can provide quite a homogeneous structure of tested polymeric materials. In addition, severe Student's t-test (for $\alpha=0.05$ ) showed that differences in wear are statistically significant $(\mathrm{p}<0.05)$ between all groups of the tested materials.

Analysis of wear profiles (Fig. 3) and wear track surface - pictures SEM (Fig. 4) indicate that abrasive wear mechanism is dominant. Microslicing is an intensifying factor. There are then traces in the form of constant cracks along the wear track. In case of iglidur $\mathrm{X}$ and P210 samples delamination was observed. In addition, there are adhesive phenomena, determined by local temperature increase as a result of friction. There has been a transfer of polymer material on metal surface of the countersample. After the tribologicals tests, it was noted that polymer particles adhered to the steel countersamples 100Cr6. As shown by the literature (Nunez and Polycarpou, 2015; Menezesa et al., 2011; Gardyński and Krzyżak, 2009; Polak, 1998) during tribological processes after a given period of time cooperation of polymer-metal pair changes into polymer-polymer co-operation, a polymer film can be then created.

Deepest wear track (Fig. 3) has been reported for material iglidur P210 and it is on average about 3x deeper in respect to the least wearable iglidur A180.

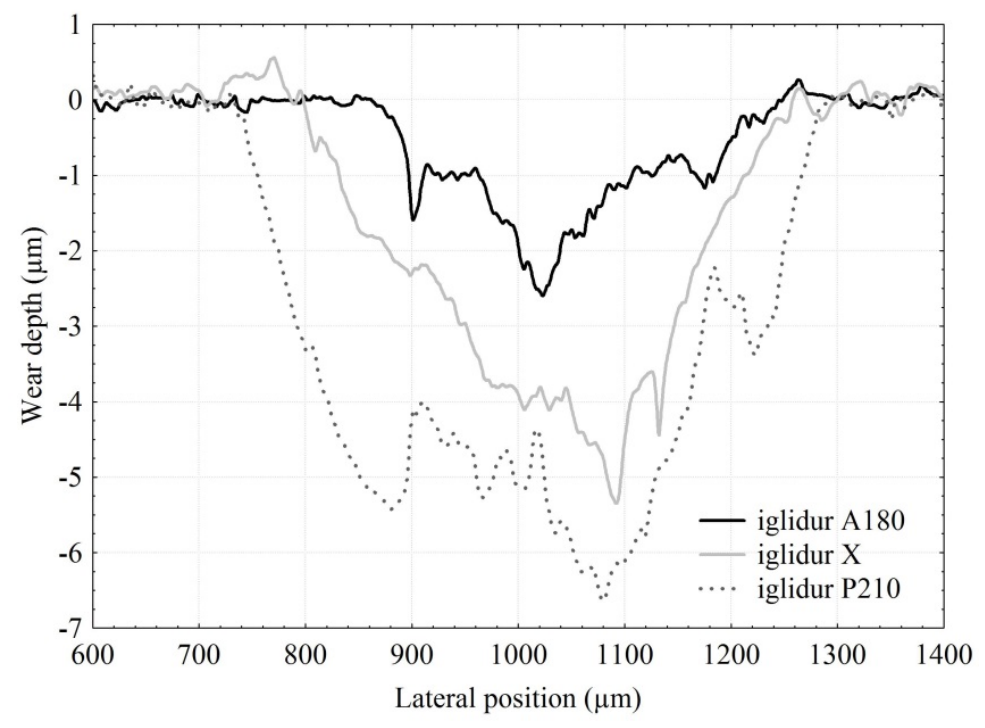

Figure 3. Typical cross-section profiles of wear tracks 
Evaluation of tribological...
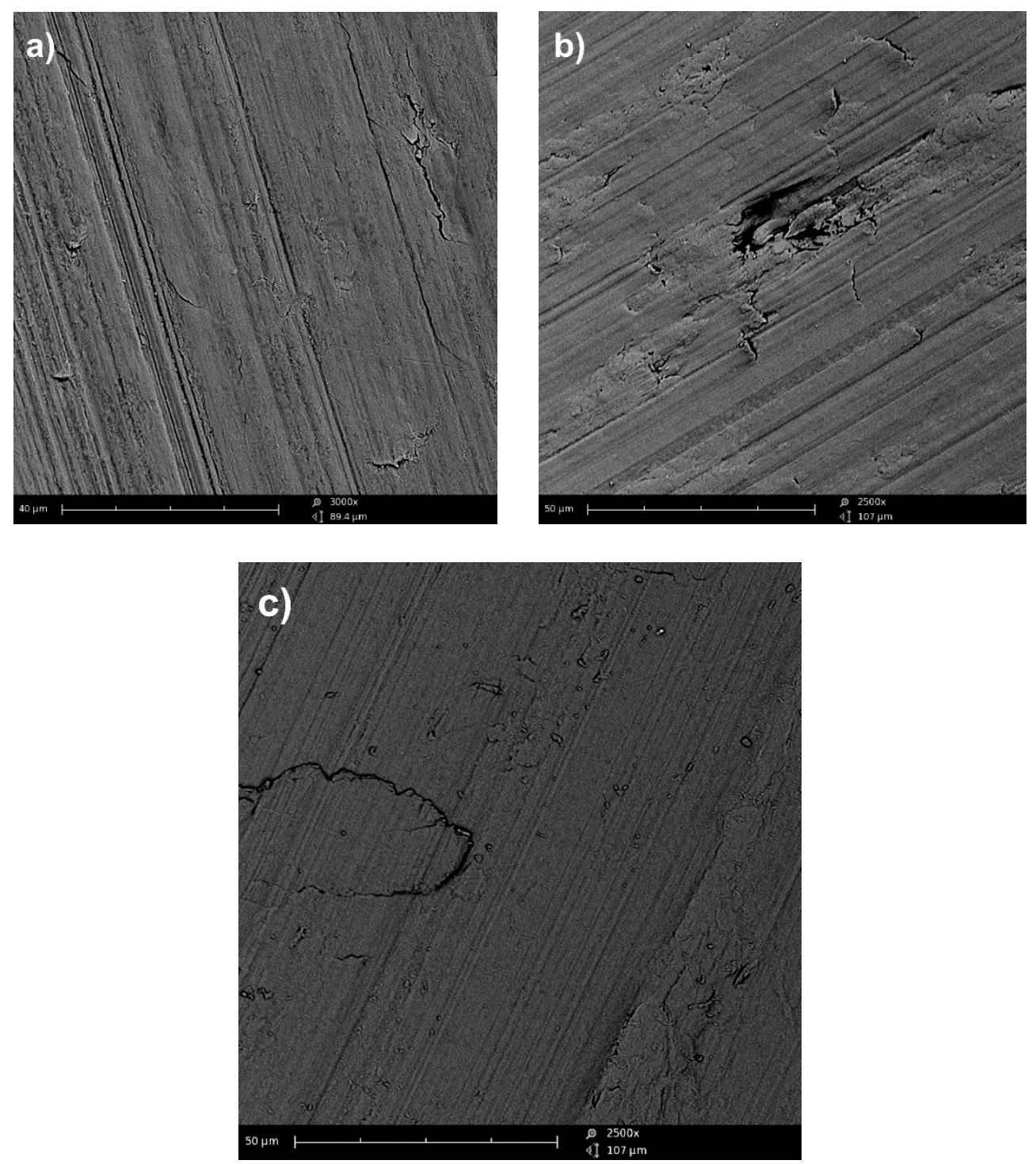

Figure 4. Representative SEM structures of wear tracks after tribological tests under conditions of technically dry frictions of the following materials: a) iglidur A180, b) iglidur $X$, and c) iglidur P210 


\section{Conclusions}

Knowledge of the technical aspects of the wear processes of machinery and equipment is essential when developing a new machine design. Knowledge of tribological characteristics and identification of polymer material wear allow developing in the future comprehensive criteria for their selection in the design of sliding bearings of agricultural machinery and equipment.

Comparative analysis of friction coefficients pointed out that the lowest coefficient is in case of the material iglidur P210 $(\mu=0.12)$ then respectively higher iglidur A180 $(\mu=0.14)$ and iglidur $X(\mu=0.19)$. In addition, among all groups of tested materials statistically significant differences ( $<<0.05$ in Student's t-test) in wear have been noted. It has been observed that, in terms of technically dry friction, the most wearable material was iglidur P210, for which in the test the lowest coefficient of friction was recorded. However, the greatest resistance to wear in the ball-on-disc test was recorded for the material iglidur A180. Essentially, the destruction mechanism of tested polymers had an abrasive nature. Furthermore, in case of iglidur X and P210 materials a delamination was found. In addition, there are adhesive phenomena associated with the transfer of polymer material on the surface of steel $100 \mathrm{Cr} 6$.

\section{References}

ASTM G 40-15. Standard Terminology Relating to Wear and Erosion.

Bahadur, S., Gong, D. (1992). Formulation of the model for optimal proportion of filler in polymer for abrasive wear resistance. Wear, vol. 157, 229-243.

Bugajski, St., Gościański, M., Łabęcki, M. (2002). Badania zmian trwałości eksploatacyjnej polimerów konstrukcyjnych, stosowanych $w$ maszynach roboczych pod wpływem procesów starzeniowych. Raport końcowy z realizacji projektu badawczego KBN, nr 7TO71304218, PIMR - Poznań.

Cenna, A.A., Allen, S., Page, N.W., Dastoor, P. (2003). Modelling the three-body abrasive wear of UHMWPE particle reinforced composites. Wear, vol. 254, 581-588.

Dykha, A.V., Kuzmenko, A.G. (2015). Solution to the Problem of Contact Wear for a Four-Ball Wear-Testing Scheme. Journal of Friction and Wear, vol. 36, no. 2, 138-143.

Friedrich, K., Cyffka, M. (1985). On the wear of reinforced thermoplastics by different abrasive papers. Wear, vol. 103, 333-344.

Gardyński, L., Krzyżak, A. (2009). Ocena wpływu oleju napędowego oraz paliwa roślinnego na zużycie tribologiczne wybranych tworzyw polimerowych. MOTROL, 11c, 51-57.

Gardyński, L., Lonkwic, P. (2014). Testing polymer rollers memory in the context of passenger lift car comfort. Journal of Vibroengineering, vol. 16, no. 1, 225-230.

Gościański, M., Kośmicki, Z., Mielec, K. (2005). Chemically polluted parts of agricultural machines which were executed from plastic. Journal of Research and Applications in Agricultural Engineering, vol. 50(4), 32-38.

Harsha, A.P. (2011). An investigation on low stress abrasive wear characteristics of high performance engineering thermoplastic polymers. Wear, vol. 271, 942-951.

Jachowicz, T., Dulebová, L. (2015). Study on the effects of mineral filler content on the p-v-T characteristics of polypropylene. Przemyst Chemiczny, vol. 94, no. 12, 2295-2298.

Jachowicz, T., Gajdoš, I. (2014). Effect of natural ageing on some properties of oxybiodegrading agent-containing polypropylene products. Przemyst Chemiczny, vol. 93, no. 11, 1983-1985. 
Evaluation of tribological...

Menezesa, P.L., Kishore, Kailas, S.V., Lovell, M.R. (2011). Friction and transfer layer formation in polymer-steel tribo-system: Role of surface texture and roughness parameters. Wear, vol. 271, 2213-2221.

Nunez, E.E., Polycarpou, A.A. (2015). The effect of surface roughness on the transfer of polymer films under unlubricated testing conditions. Wear, vol. 326-327, 74-83.

Polak, A. (1998). Przenoszenie materiału $w$ tożysku ślizgowym stal-tworzywo sztuczne. Seria Mechanika, Monografia 233, Zakład graficzny Politechniki Krakowskiej, Kraków.

Ptak, A. (2016). The influence of the motion parameters on the surface layer of metal-polymer sliding pairs at low temperatures. Triblogia, 1(265), 79-87.

Shipway, P.H., Ngao, N.K. (2003). Microscale abrasive wear of polymeric materials. Wear, vol. 255, $742-750$.

Szczerba, J. (2013). Techniki wspomagania projektowania wyrobów z tworzyw sztucznych. Aplikacja do doboru tworzyw polimerowych do wybranych zastosowań. Mechanik, 3, 218-224.

Szczerek, M., Tuszyński, W. (2002). A method for testing lubricants under conditions of scuffing. Part I. Presentation of the method. Tribotest journal no. 8, 273-284.

Tomczyk, W. (2005). Uwarunkowania racjonalnego procesu użytkowania maszyn i urządzeń rolniczych. Inżynieria Rolnicza, 7, 359-366.

\section{OCENA WLAŚCIWOŚCI TRIBOLOGICZNYCH MATERIALÓW POLIMEROWYCH STOSOWANYCH NA LOŻYSKA ŚLIZGOWE MASZYN ROLNICZYCH}

Streszczenie. Ciągły rozwój technologiczny, wymusza stosowanie nowoczesnych materiałów konstrukcyjnych również w inżynierii rolniczej. Znajomość charakterystyki tribologicznej materiałów par współpracujących ze sobą, jest przydatna do opracowania skojarzeń ślizgowych maszyn rolniczych. Przy wyborze materiałów technologicznych poza kryterium ekonomicznym powinna być ocena właściwości tribologicznych materiałów. W artykule przedstawiono analizę charakterystyki zużycia tribologicznego ball-on-disc materiałów polimerowych stosowanych jako elementy ślizgowe maszyn rolniczych. Próby tribologiczne przeprowadzono w atmosferze tarcia technicznie suchego dla pary metal-polimer. Badano współczynnik zużycia i współczynnik tarcia próbek, a ślady zużycia poddano obserwacjom SEM.

Słowa kluczowe: współczynnik tarcia, łożyska ślizgowe, test ball-on-disc, zużycie, tribologia 